\title{
Audit Quality and Earnings Management in the Tunisian Context
}

\author{
ZGARNI Inaam (Corresponding author) \\ Ph. D student in Accounting: Faculty of Economics and Management, University of Sfax, \\ Tunisia. \\ E-mail: inaamezgarni@yahoo.fr, Ph: (+216)22883038
}

\section{HLIOUI Khmoussi}

Professor of Accounting: College of Economics, Management and Information System, University of Nizwa, Sultanate Oman.

E-mail: khamoussi.halioui@gmail.com

\section{ZEHRI Fatma}

Associate Professor of Accounting: Faculty of Economics and Management, University of Sfax, Tunisia

Received: July 07, 2012 Accepted: August 03, 2012 DOI: 10.5296/ijafr.v2i2.2065

\begin{abstract}
In this study, we test the effect of the implementation of the financial security law ( $n^{\circ} 2005-96$ ) and the audit quality (Big 4 auditors, auditor industry specialization and audit tenure) on constraining the extent of real and accruals based earnings management in the Tunisian context. Using 319 firm-year observations during the period 2000-2010, our results suggest that auditor industry specialization and Big 4 auditors associated with lower levels of accruals earnings management. We also find that the Big 4 auditors enhance the extent of real earnings management (REM). Further, we document that longer auditor tenure is not associated with greater real and accruals earnings management. Finally, our findings suggest that the adoption of the financial securities law of 2005 is not effective on reducing earnings management in the Tunisian context.
\end{abstract}

Keywords: Real earnings management, discretionary accruals, audit quality 


\section{Introduction}

Accounting scandals that have been experienced in the last few years such as Enron, Arthur Andersen and World Com have affected the regulators trust of financial statements. This scandal and its subsequent results were a main reason for drawing attention towards the quality of financial statements. Moreover, the financial crisis which has affected most of the world in the recent years has pushed up the demand for high audit quality. This result may signal that auditors are being more watchful after such crisis and that they now tend to perform their work in a highly ethical and ensure the high quality of their work. Thus, audit quality is a one of the main factors that affect the credibility of financial information. This can be a motivation for deep research on audit quality and the factors that may affect it.

Audit quality is defined as the probability that an auditor will both discover a breach in the accounting system and further report the breach. The discovery of a misstatement measures quality in terms of the auditor's knowledge and ability, while the reporting of a misstatement is dependent on the auditor's incentives to disclose (DeAngelo, 1981). The probability that an auditor will detect a breach depends largely on the probability of discovery, which is related to the auditors' competence. Similarly, the probability that an auditor will report the detected breach is related to the auditors' independence. Thus, the auditors should provide a professional opinion regarding the reliability of the information contained in the financial statements. Yet, the audit process carried out by auditors is not directly observable (Balsam et al., 2003). Therefore, the audit activity is not objectively measurable and that the evaluation of the quality of the audit services must be based on indirect signals. Previous research on audit quality (Becker, 1998; Francis and Yu, 2009; Choi et al., 2010) has focused on either factors contributing to audit quality or consequences of audit quality. In this study we will study the factors which contribute to audit quality: auditor-specific characteristics, big 4 auditors, industry specialization of auditor and auditor tenure.

Prior research on earnings management has studied the manipulation of discretionary accruals (Jones, 1991; Dechow et al., 1995), real transactions (Graham et al., 2005; Roychowdhury, 2006; Gunny, 2010) or both (Zhang, 2007; Cohen and Zarowin, 2010). Hence, Abundant research indicates higher audit quality mitigates the earnings management (Becker et al., 1998; Francis and Yu, 2009; Lin and Huang, 2010; Jordan et al., 2010) and there are relatively fewer studies examining the impact of audit quality on real earnings management (Chi and al., 2011; Cohen and Zarowin, 2010). Furthermore, empirical evidence on audit quality measures has been mixed. For example, while many existing studies show that the use of brand name (Big N) auditors reduces earnings management (Becker et al., 1998; Francis et al., 1999; Lim and Tan, 2009) many other studies show that industry specialist auditors and short tenure of audit have the abilities and incentives to detect and constrain accounting-based earnings management (Krishnan, 2003; Riechelt and Wang, 2010; Ahsen, 2011; Johnson et al., 2002).

The auditors are obviously doing their functions, duties and responsibilities though potentially implementing auditing standards, rules and regulations in order to increase the reliabilities of themselves and other outcomes and performances. In 2005, the financial security law was set up in Tunisia. This Act (law n 2005-96 of 18 October 2005) seeks to achieve greater transparency and improve the credibility of financial information by 


\section{Mll Macrothink}

International Journal of Accounting and Financial Reporting ISSN 2162-3082 2012, Vol. 2, No. 2

regulating auditor's independence and expertise in listed companies. This law requires the mandatory rotation of audit firms. According to the Tunisian regulation, the auditor term could be renewed every three years and could be extended up to a maximum tenure of nine years. This means that in Tunisia, there was both retention and a rotation rule. Once appointed, the audit firm was retained for at least three years. At the end of each three-year period, the firm had to decide whether to renew the appointment of the auditor. After nine consecutive years of engagement, change of the audit firm was mandatory. This rule was issued to preserve auditor independence based on the assumption that such independence could be compromised of a long-term relationship between the auditor and the firm. Therefore, the Tunisian institutional setting allows us to test the effects of auditor tenure and auditor change in an actual mandatory rotation environment. Consequently, the auditor should be independent from management to be able to conduct effective monitoring which results in less opportunistic management behavior.

This paper is aimed (1) to determine if significant associations exist between audit quality and the occurrence of discretionary accruals and REM and (2) to test the effect of law $\mathrm{n}^{\circ}$ 2005-96 on the relationship between the probability of earnings management and audit quality. Using three different measures of audit quality (size, tenure and industry specialization of auditor) based on a sample of 319 non-financial Tunisian listed firms from 2000 to 2010. In this study the absolute value of discretionary accruals is used as a proxy for accounting earnings management by using a cross-sectional variation of the modified Jones model of 1995. We measure the REM (sales manipulation, reduction of discretionary expenditures and overproduction) by using the model of Roychowdhury (2006).

The paper proceeds as follows. Section 2 reviews the extant literature and develops our research hypotheses. Section 3 explains how we measure our research variables and specifies our empirical model used for hypothesis testing. Section 4 describes our sample and data sources and presents empirical results. Finally, last section presents our conclusions.

\section{Background and Hypothesis Development}

Jensen and Meckling (1976) suggest that auditing is an important means of mitigating agency conflicts between managers and outside shareholders. Auditing is a monitoring device for the shareholders because auditors would report detected material misstatements in audited financial statements. In short, auditing is also a bonding device of the managers who engage auditors to signal to the shareholders that they will not behave opportunistically.

Zang (2007), Roychowdhury (2006) and Cohen and Zarowin (2010) discuss and document that managers exercise their discretion not only via choice of accounting estimate and methods (accrual-based earnings management) but also through operational decisions (real activities manipulation). Real activities manipulation is an alternative tool of earnings management through changing operating activities and decisions (opportunistic reduction of discretionary expenses, overproduction, and offering price discounts to boost current-period sales). Separately, Graham et al. (2005) suggest that given the stigma associated with accrual management, earnings manipulations are now more likely to be achieved through real economic actions. First, accrual-based earnings management is more likely to draw auditor or regulatory scrutiny than real decisions, such as those related to product pricing, production, 
and expenditures on research and development or advertising. Second, relying on accrual manipulation alone is risky. The realized shortfall between unmanaged earnings and the desired threshold can exceed the amount by which it is possible to manipulate accruals after the end of the fiscal period. If reported income falls below the threshold and all accrual-based strategies to meet it are exhausted, managers are left with no options because real activities cannot be adjusted at or after the end of the fiscal reporting period.

Several prior studies document that a higher auditor quality (auditor size, industry specialization and tenure) mitigate the accruals earnings management (Becker et al. 1998; Johnson et al. 2002; Krishnan 2003; Balsam et al. 2003; Myers et al. 2003). But, fewer researches indicate that the higher audit quality enhance the real earnings management. Chi et al. (2011) investigate the relation between audit quality and real earnings management and find that both auditor industry expertise and the presence of a Big $\mathrm{N}$ audit firm are associated with greater real earnings management. They argue that, as increased audit scrutiny may decrease a firm's accounting flexibility, firms audited by Big $\mathrm{N}$ are likely to resort to the more costly real earnings management. Similarly, Cohen and Zarowin (2010) find that both auditor tenure and the presence of Big $\mathrm{N}$ auditors are associated with greater probability of using real earnings management.

\section{1. Auditor size and earnings management}

DeAngelo (1981) argues that Big 6 auditors provide better audit quality than non-Big 6 auditors, which is supported by extensive subsequent empirical research. Similarly, Becker et al. (1998) found that companies with non-Big 5 auditors (a proxy for lower audit quality) report discretionary accruals that significantly increase income compared to companies with Big 5 auditors. In addition, Krishnan (2003) demonstrate that Big 4 auditors are better at constraining client earnings management compared to non-Big 4 auditors; they find that clients of non-Big 4 auditors have higher levels of discretionary accruals. In the same context, Zhou and Elder (2003) and Ahsen (2011) find that Big 4 auditors associate with less earnings management in the firms. Indeed, Big 4 audit companies are assumed to have higher audit quality than non-Big 4, because they are less dependent on their clients. Similarly, Francis and $\mathrm{Yu}$ (2009) and Choi et al. (2010) have shown that audit office size is a primary determinant of audit quality. The two studies show that audit quality is higher for clients of large audit offices of Big 4 firms than for clients of smaller offices. Clients served by larger offices have lower absolute discretionary accruals, are less likely to report small positive earnings or small increases in earnings from the prior year, and larger offices are more likely to issue a modified audit report. However, Lawrence et al. (2011) suggest that these results may be driven by differences in client characteristics. They use matching models to control client characteristics and find that the audit quality of Big 4 auditors does not differ significantly from that of non Big 4 auditors. Further, Francis and Wang (2008) report that the decrease of the magnitude of accruals earnings management is restricted to the clients of Big 4 auditors in the U.S. (in which legal regime is the strongest in the world) and those of non-Big 4 auditors are not affected by the legal regime changes. As a result, it is possible that auditors do not play any monitoring for the decrease of REM because the REM is harder for external auditors, regulators and other stakeholders to detect compared with AEM. One exception is Kim et al. (2003), who provide empirical evidence that Big auditors are less 


\section{Mll Macrothink}

International Journal of Accounting and Financial Reporting ISSN 2162-3082 2012, Vol. 2, No. 2

effective than non-Big auditors in monitoring income decreasing earnings management. Yet other few studies have focused on relation between REM and the Big N. Chi et al. (2011) find that the presence of a Big $\mathrm{N}$ is associated with greater REM. They argue that, as increased audit scrutiny may decrease a firm's accounting flexibility, firms audited by Big N are likely to resort to the more costly real earnings management. Similarly, Cohen and Zarowin (2010) provide additional evidence that both accrual and real management tools are used together. They also find that Big 8 auditors are positively related to real earnings management, suggesting that more effective monitoring may motivate firms to manage earnings using techniques that are more difficult to identify. Hence, a negative association between earnings management and audit firm size is expected. We expect also, a positive relation between the real earnings management and the auditor's size. Therefore, the hypotheses are stated in the following alternative forms.

$H_{1.1}$ : There is a significant negative association between auditor size and the occurrence of accruals based earnings management.

$H_{1.2}$ : There is a significant positive association between auditor size and the real earnings management.

\section{2. Industry specialization and earnings management}

Auditor industry specialization represents an important dimension of audit quality. A specialist's knowledge of the industry is developed through extensive auditing experience, specialized staff training, and expensive investments in information technology. Relative to non-specialist auditors, this industry knowledge enables specialist auditors to provide higher quality audit service to the clients by constrain management's discretionary behavior. Thus, industry specialization is an important way in which audit firms can differentiate themselves from their competitors. Ahsen (2011) has shown that firms audited by industry specialist auditors are associated with higher earnings quality. In addition, Kwon et al. (2007) extend evaluation of the impact of specialist auditors on earnings quality of firms across countries and they document that audit by industry specialists is especially effective in improving earnings quality in countries with weak legal environment. However, Jaggi et al. (2012) indicate that Kwon et al.'s results are valid only for countries with weak investor protection reflected by the proportional electoral system and not for countries with strong investor protection reflected by the electoral system. Lim and Tan (2009) reveal that firms audited by specialists (vs. non-specialists) have relatively higher audit quality (using accrual quality as the proxy). In the same context, Rusmin (2010) argue that the discretionary accruals of industry specialist auditor clients are lower than discretionary accruals of non-industry specialist clients. Similarly, Dunn and Mayhew (2004) confirm that the use of an auditor with industry specialization will help curb earnings management. These findings are consistent with the theory that auditors specialize in various industries to achieve product differentiation and provide higher audit quality. Therefore, Krishnan (2003) finds that clients of firm-level industry experts report earnings more conservatively. Gul et al. (2010) find that industry expertise partially mitigates the effects of short auditor tenure on earnings quality, as measured by discretionary accruals. However, Chen et al. (2005) find a positive relationship. Jaggi et al. (2012) show that the positive association between industry specialist auditors and earnings quality as documented in the literature is affected by the political electoral system, 


\section{Mll Macrothink}

International Journal of Accounting and Financial Reporting ISSN 2162-3082 2012, Vol. 2, No. 2

which reflects investor protection rights in a country. We document that audits by industry specialists are associated with higher earnings quality in countries with the proportional electoral system, reflecting weak investor protection. Further, Lawrence et al. (2011) find no association between industry specialization and absolute discretionary accruals. The majority of these findings suggest that auditors with industry expertise are more likely to detect misrepresentations and irregularities than auditors without industry expertise. The linkage is based on the assumption that industry-specialist auditors have the industry expertise that results in better understanding of the client's business. Therefore, the constraints of accruals-based manipulation from industry specialist auditors may motivate managers to alter real activities during the year with the specific objective of meeting earnings targets. Chi et al. (2011) find that auditor industry expertise is associated with greater real earnings management. Thus, we expect that with the increase of auditor industry specialization the accruals earnings manipulation will diminish. We expect also a positive association between real earnings manipulation and industry specialization.

$H_{2.1}$ : There is a significantly negative association between auditor industry specialization and the occurrence of accruals based earnings management.

$H_{2.2}$ : There is a significantly positive association between auditor industry specialization and the occurrence of real earnings management.

\section{3. Auditor tenure and earnings management}

Myers et al. (2003) defined auditor tenure as the number of years an auditor is retained by the firm. Balsam et al. (2003), Reichelt and Wang (2010) and Jerry et al. (2010) reported a significant negative relationship between auditor tenure and earnings management. Yet, Gul et al. (2010) reported higher levels of positive discretionary accruals in the early years of the auditor-client relationship. However, Johnson et al. (2002) found that clients with shorter auditor tenure (less than four years) have lower accrual quality than those with longer auditor tenure (4-8) years, but finds no significant difference in accrual quality between firms with 4 from 8 year auditor tenure and those with auditor-client relationships longer than 8 years. Further, Davis et al. (2009) demonstrated that both short and long-term auditor engagements were associated with the increased use of discretionary accruals to meet and beat earnings forecasts in the pre-SOX period but that the results disappeared following SOX. In addition, Jenkins and Velury (2008) document a positive association between the level of conservatism in reported earnings and the length of the auditor client relationship. In particular, they find an increase in conservatism between short and medium tenure that does not deteriorate over a long tenure, and they conclude that a mandatory auditor rotation rule might have an adverse effect in terms of earnings conservatism. Simnett (2006) and Jackson et al. (2008) found no relation between audit partner tenure and the absolute value of discretionary accruals. Therefore, the constraints of accruals-based manipulation from auditor tenure may motivate managers to alter real activities during the year with the specific objective of meeting earnings targets. Chi et al. (2011) and Cohen and Zarowin (2010) find that auditor tenure is associated with greater probability of using real earnings management.

The financial security law $\mathrm{n}^{\circ} 2005-96$ requires a mandatory auditor rotation regime; the auditors know in advance that their tenure will end on a given date. Such awareness might 
affect their incentives in performing audit activities. Thus, deterioration of audit quality over time may also be a consequence of the auditor becoming less independent from the client firm. Consequently, the financial security law $n^{\circ} 2005-96$ support the hypothesis that longer tenure is associated with increaser the values of, in the hand, absolute discretionary accruals and in other hand, real earnings management in the Tunisian context. Hence, the followings hypothesis is proposed:

$H_{3.1}$ : There is a significantly positive association between auditor tenure and the occurrence of accruals based earnings management.

$H_{3.2}$ : There is a significantly positive association between auditor tenure and the occurrence of real earnings management.

\section{Sample and Data Collection}

In addressing the concerns enumerated in the study objectives, we adopt a deductive research approach and quantitative research strategy. The sample has been selected from the Tunis Stock Exchange comprising 29 listed companies and excludes: (1) Financial Institutions (given their specific capital structure and profits), (2) Companies for which the data could not be found. We collect our data from different sources especially annual reports, web sites and direct contacts.

\section{1. Measurement of Accrual earnings management}

In order to analyze the effect of audit quality on the earnings management, discretionary accruals was used to measure earnings management (AEM) as the dependent variable. The practice of using discretionary accruals to proxy for AEM is consistent with the extant AEM literature (Yu, 2008 and Cohen et al., 2008). While there are many ways to estimate discretionary accruals, this study employs the Modified-Jones Model of 1995 (Dechow et al, 1995). The Modified-Jones Model has been shown to outperform other discretionary accrual models in detecting AEM. We estimate the following equation:

\section{$\mathrm{ACCR}_{\mathrm{it}}=\alpha_{0}+\alpha_{1}\left(\Delta \mathrm{REV} V_{\mathrm{it}}-\Delta \mathrm{REC} \mathrm{C}_{\mathrm{it}}\right)+\alpha_{2} \mathrm{PPE}_{\mathrm{it}}+\varepsilon_{\mathrm{it}}$}

where $A_{C C R}$ is the total accruals; $\triangle \mathrm{REV}_{\text {it }}$ is the change in revenue measured by change in sales it relative to sales it-1; $\triangle \mathrm{REC}_{\mathrm{it}}$ is the change in net account receivable in year t relative to year $\mathrm{t}-1$ and $\mathrm{PPE}_{\mathrm{it}}$ is the gross value of property, plant and equipment in year $\mathrm{t}$.

\section{2. Measures of REM}

Following the prior studies on REM (Roychowdhury 2006; Gunny 2010; Zang 2007), we examine the following real activities manipulation: sales manipulation, reduction of discretionary expenditures, and overproduction. We measure the abnormal level of each type of REM as the residual from the relevant estimation model. Roychowdhury (2006) defines sales manipulation as managers' attempts to temporarily increase sales during the year by offering price discounts or more lenient credit terms, which lowers the cash inflow per sale. Hence, sales manipulation is expected to lead to lower current-period CFO. We use Roychowdhury's (2006) model to estimate the normal level of CFO:

\section{$C F O_{t} / A_{t-1}=\alpha_{0}+\alpha_{1}\left(1 / A_{t-1}\right)+\beta_{1}\left(S_{t} / A_{t-1}\right)+\beta_{2}\left(\Delta S_{t} / A_{t-1}\right)+\varepsilon_{t}$}

Where $\mathrm{CFO}=$ Cash flow from operations; $\mathrm{S}=$ Net sales; $\mathrm{A}=$ Total assets.

This model is developed based on Dechow et al. (1998). The normal level of CFO is 


\section{Macrothink}

International Journal of Accounting and Financial Reporting

ISSN 2162-3082

2012, Vol. 2, No. 2

expressed as a linear function of sales and change in sales. For every firm-year, abnormal cash flow from operations (ABCFO) is the difference between the actual $\mathrm{CFO}$ and the expected CFO calculated using the corresponding industry-year model.

Another type of REM is the reduction of discretionary expenses. If managers reduce discretionary expenditures ( $R \& D$, advertising and SG\&A expenses) to boost earnings to the targets, abnormally low discretionary expenses are expected. Following Roychowdhury (2006), I estimate the normal level of discretionary expenses using the equation below:

$\operatorname{EXP}_{t} / A_{t-1}=\alpha_{0}+\alpha_{1}\left(1 / A_{t-1}\right)+\beta_{1}\left(S_{t-1} / A_{t-1}\right)+\varepsilon_{t}$

Where EXP $=$ Discretionary expenses $=\mathrm{R} \& \mathrm{D}+$ Advertising + Selling, General and Administrative expenses; $\mathrm{S}=$ Net sales; $\mathrm{A}=$ Total assets.

The third type of real activities manipulation is to produce more goods than necessary to meet expected demand (overproduction). Overproduction reduces cost of goods sold (CGS), which results in higher operating margin. However, additional holding and production costs may be incurred and are very likely to increase marginal costs, which results in higher annual production costs relative to sales. We use Roychowdhury's (2006) model to estimate the normal level of production costs.

Production costs are defined as the sum of CGS and change in inventory (INV) during the year. We model CGS as a linear function of contemporaneous sales:

$\mathrm{CGS}_{\mathrm{t}} / \mathrm{A}_{\mathrm{t}-1}=\alpha_{0}+\alpha_{1}\left(1 / \mathrm{A}_{\mathrm{t}-1}\right)+\beta_{1}\left(\mathrm{~S}_{\mathrm{t}} / \mathrm{A}_{\mathrm{t}-1}\right)+\varepsilon_{\mathrm{t}}$

Next, we model inventory growth by the following equation:

$\Delta I N V_{t} / A_{t-1}=\alpha_{0}+\alpha_{1}\left(1 / A_{t-1}\right)+\beta_{1}\left(\Delta S_{t} / A_{t-1}\right)+\beta_{2}\left(\Delta S_{t-1} / A_{t-1}\right)+\varepsilon_{t}$

Using Equations (a) and (b), we estimate the normal level of production costs (PROD) as follows:

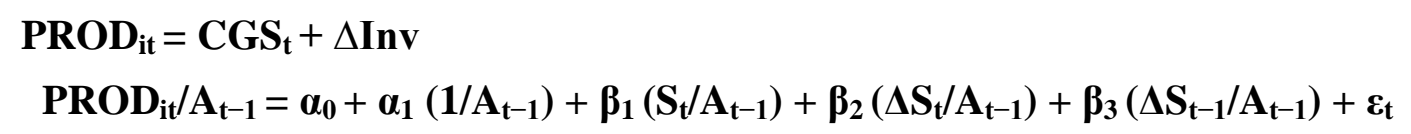

This model is based on the model presented in Dechow et al. (1998); these authors have found that CGS and changes in inventory are associated with sales and changes in sales. For every firm-year, abnormal production cost is the difference between the actual production costs and the expected production costs calculated using the corresponding industry-year model.

\section{3. Measurement of audit quality}

We show in table 1 the measurements of the independent variables (proxy of audit quality: auditor size, industry specialization and tenure of auditor). 


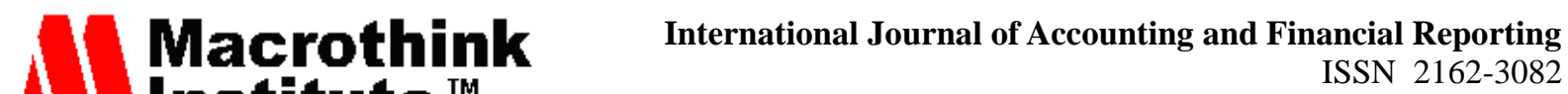 Institute ${ }^{\text {TM }}$

Table 1: Measurement of independent variables

\begin{tabular}{||l||l||}
\hline Independent variables & Measurements \\
\hline \hline AudSIZE & $\begin{array}{l}\text { a dummy variable, } 1 \text { if the firm is audited by } \\
\text { a Big } 4 \text { auditor, } 0 \text { otherwise. }\end{array}$ \\
\hline \hline SPEC & $\begin{array}{l}\text { a dummy variable, } 1 \text { if } \mathrm{MS}>10 \text { percent, and } \\
0 \text { otherwise. } \\
\text { where: } \mathrm{MS}=\mathrm{m}-\mathrm{firm} \text { sales ratio }=\sum=\mathrm{S}_{\mathrm{ij}} / \mathrm{s}_{1} \\
\left(\mathrm{~S}_{\mathrm{ij}}=\text { firm } \mathrm{i} \text { 's sales, while firm } \mathrm{i} \text { is audited by }\right. \\
\text { auditor } \mathrm{j} \text { and } \mathrm{S}_{1}=\text { the sum of sales for all } \\
\text { firms in the industry. }\end{array}$ \\
\hline \hline TENURE & $\begin{array}{l}\text { number of consecutive years the client has } \\
\text { retained a particular audit firm. }\end{array}$ \\
\hline
\end{tabular}

\section{4. Measurement of Control variables}

In line with previous literature we include a set of control variables that are associated with the level of earnings management. Size is included because larger firms tend to have lower absolute abnormal accruals (Becker et al. 1998; Myers et al. 2003; Francis and Wang 2008; Lim and Tan 2009; Reichelt and Wang 2010). Firm size is defined as the natural logarithm of total assets at the end of period (LOGSIZE it $=\log \left(\mathrm{A}_{\mathrm{i}, \mathrm{t}}\right)$ ). We also expect earnings management to be higher leverage (LEV). Thus, LEV is the ratio of debt to total asset at the beginning of current year. $\mathrm{LEV}_{\mathrm{i}, \mathrm{t}}=\mathrm{DEBT}_{\mathrm{i}, \mathrm{t}} / \mathrm{A}_{\mathrm{i}, \mathrm{t}}$. In addition, we expect earnings management to be higher for firms with more growth opportunities (MTB $=$ The ratio of market value of common equity to book value). Moreover, we include return on assets (ROA) as an additional variable to control for the nondiscretionary component of accruals that is not extracted by our accrual model. $\mathrm{ROA}=$ Return on assets, computed as net income before extraordinary items divided by lagged total assets.

\section{5. Regression Model}

A first linear-multiple regression analysis was used to test the association between the dependent variable AEM and the independent variables audit quality. The following model is estimated:

DA $_{i, t}=\beta_{0}+\beta_{1}$ AudSIZE $_{i, t}+\beta 2$ SPEC $_{i, t}+\beta 3$ TENURE $_{i, t}+\beta 4$ LOGSIZE $_{i, t}+\beta_{5}$ MTB $_{i, t}+\beta_{7}$ $\operatorname{LEV}_{\mathrm{i}, \mathrm{t}}+\beta_{\mathbf{8}} \mathrm{ROA}_{\mathrm{i}, \mathrm{t}} \varepsilon_{\mathrm{i}, \mathrm{t}}$

A second linear-multiple regression analysis was used to test the association between the REM and the audit quality. The following model is estimated:

Sales manipulation $=\beta_{0}+\beta_{1}$ AudSIZE $_{i, t}+\beta 2$ SPEC $_{i, t}+\beta 3$ TENURE $_{i, t}+\beta 4$ LOGSIZE $_{i, t}+$ $\beta_{5}$ MTB $_{i, t}+\beta_{7} \operatorname{LEV}_{\mathrm{i}, \mathrm{t}}+\beta_{8} \mathrm{ROA}_{\mathrm{i}, \mathrm{t}} \varepsilon_{\mathrm{i}, \mathrm{t}}$

Abnormal discretionary expenses $=\beta_{0}+\beta_{1}$ AudSIZE $_{i, t}+\beta 2$ SPEC $_{i, t}+\beta 3$ TENURE $_{i, t}+\beta 4$ $\operatorname{LOGSIZE~}_{\mathrm{i}, \mathrm{t}}+\beta_{5}$ MTB $_{\mathrm{i}, \mathrm{t}, \mathrm{i}}+\beta_{7} \operatorname{LEV}_{\mathrm{i}, \mathrm{t}}+\beta_{8} \operatorname{ROA}_{\mathrm{i}, \mathrm{t}} \varepsilon_{\mathrm{i}, \mathrm{t}}$

Abnormal production costs $=\beta_{0}+\beta_{1}$ AudSIZE $_{i, t}+\beta 2$ SPEC $_{i, t}+\beta 3$ TENURE $_{i, t}+\beta 4$ 
$\operatorname{LOGSIZE~}_{i, t}+\beta_{5}$ MTB $_{i, t} \mathrm{i}, \mathrm{t}+\beta_{7} \operatorname{LEV}_{\mathrm{i}, \mathrm{t}}+\beta_{8}$ ROA $_{\mathrm{i}, \mathrm{t}} \varepsilon_{\mathrm{i}, \mathrm{t}}$

\section{Empirical Results}

\section{1. Descriptive Statistics}

Table 2 provides descriptive statistics of the variables used in the study.

Table 2: Descriptive statistics (Pooled Sample; $\mathbf{n = 3 1 9 )}$

\begin{tabular}{|l||l|l|l||l|}
\hline Variable & Mean & Std. Dev. & Min & Max \\
\hline DA & 0,043938 & 0,2369817 & 0,1365484 & 3,129765 \\
\hline \hline REM & 0,032167 & 1,032762 & $-1,0563721$ & 0,408766 \\
\hline \hline AudSIZE & 0,313479 & 0,464636 & 0 & 1 \\
\hline SPEC & 0,319749 & 0,467112 & 0 & 1 \\
\hline TENURE & 3,987461 & 2,657581 & 0 & 10 \\
\hline \hline MTB & 0,245487 & 0,063258 & 0,068213 & 0,442983 \\
\hline LOGSIZE & 7,495354 & 2,695202 & 0,515250 & 8,460369 \\
\hline \hline LEV & 0,458724 & 0,211359 & 0 & 0,658421 \\
\hline \hline ROA & 0,156971 & 1,552206 & $-0,640229$ & 0,53655 \\
\hline
\end{tabular}

Where, REM is the sum of sales manipulations, discretionary expenses and overproduction

Table 2 shows the mean value of absolute discretionary accruals and REM are $6.42 \%$ and $3.21 \%$ of total assets respectively in the Tunisian context. This results indicating that the magnitude of REM is lower than discretionary accruals. Table 2 reveals that Big 4 auditors represent a $31.3 \%$ of the sampled companies, while companies audited by the non-Big 4 audit firms represent less than $68.7 \%$ of the sample. In addition, the overall mean of industry specialization (SEPC) is $31.9 \%$; this indicates that the big 4 auditors and the industry specialization of auditor are of the same order of magnitude. Thus, the Tunisian firms are audited by Big 4 industry specialists. Furthermore, the mean of audit tenure is (TENURE) 4 years. The financial security law of 2005 predicts that auditor term could be renewed every three years and could be extended up to a maximum tenure of nine years. This means that in Tunisia, there is a rotation rule. For The MTB, we note that the mean value is $24.5 \%$. The ratio of LEV is 45.87 with a standard deviation of 0.211 . While the mean of firm size, measured by the natural logarithm of total assets, is 7.49 with a standard deviation of 2.69.

\section{2. Tests on panel data}

We note that the estimations of our models are made on panel data since the regressions that enable us to check for some tests are in about two dimensions: one temporal and the other individual. Firstly, we calculate the Pearson correlation and VIF for independent variables to detect the multicollinearity between these variables. Secondly, we affect the heteroscedasticity test to verify if the square of the residues can be explained by explanatory 
variables of the model. Finally, we use the Hausman test to approve if exist the individual effect.

\section{2. 1. Multivariate analysis}

To assess if our sample suffered from multicolinearity, we have calculated the Pearson correlation coefficient (Table 3) and Variance inflation factors (Table 4) for independent variables. As expected, there is a positive correlation between the Big 4 and industry specialist variables, since all specialists firms are Big 4 firms. Tenure is not associated with Big 4 and is positively associated with the industry specialization. Large firms are more likely to use Big 4 firms and industry specialist auditors. This suggests that Big 4 auditors and industry specialists provide higher quality of auditing which forces firms to exercise less discretion. Although some variables are significantly correlated with each other, multicollinearity was deemed not to be a problem for regression analysis due to inconsequential variance inflation factors.

Table 3: Pearson's correlation matrix

\begin{tabular}{|l||l|l|l|l|l|l|l||}
\hline & AudSIZE & SPEC & TENURE & MTB & LOGSIZE & LEV & ROA \\
\hline AudSIZE & 1,0000 & & & & & & \\
\hline \hline SPEC & $0,2991^{*}$ & 1,0000 & & & & & \\
\hline \hline TENURE & 0,0434 & $0,039 *$ & 1,0000 & & & & \\
\hline \hline MTB & $0,1315^{*} *$ & 0,0696 & $0,0307^{*}$ & 1,0000 & & & \\
\hline \hline LOGSIZE & $-0,0108$ & 0,0193 & $-0,0858^{* *}$ & $-0,0307^{*}$ & 1,0000 & & \\
\hline \hline LEV & $0,0873^{*}$ & 0,0798 & 0,0544 & $-0,0151^{*}$ & 0,0544 & 1,0000 & \\
\hline ROA & $-0,0376$ & 0,0523 & $-0,0347^{* *}$ & $0,0131^{*}$ & $0,0432 *$ & 0,0057 & 1,0000 \\
\hline \hline
\end{tabular}

The sample consists of 319 firm-year observations for the period 2000-2010 corresponding to 29 firms. The correlation coefficients are based on Pearson product momentum correlations. $*$ and $* *$ represent statistical significance at 0.05 and 0.10 level respectively.

Table 4: Variance inflation factors of the audit quality

\begin{tabular}{|l|l||l|l|l||l|l||l||}
\hline Variables & REPUT & SPEC & TENURE & MTB & LOGSIZE & LEV & ROA \\
\hline \hline VIF & 1,03 & 1,02 & 1,01 & 2,02 & 1,06 & 2,03 & 1,04 \\
\hline
\end{tabular}

Table 3 and 4 reported that the results of the Pearson correlation and Variance inflation factors of the proxy of the audit quality. We can say that the correlations between independent variables are significant at 5 and $10 \%$. Furthermore, none of the correlation coefficients is so high (>0.85) as to present significant multicolinearity problems (Archambeault and DeZoort, 2001). In addition, Table 4 shows the absence of multicollinearity problem between the independent variables (Vif don't exceed the value of 3 and 1/Vif exceed the value of 0.05). 


\section{Macrothink}

International Journal of Accounting and Financial Reporting

ISSN 2162-3082 2012, Vol. 2, No. 2

\section{2. 2. Heteroscedasticity test}

Besides, we verify the hypotheses of homoscedasticity while using Breush-Pagan test (Table 5). The rationale behind these tests is to verify if the square of the residues can be explained by explanatory variables of the model. Table 5 shows the results of Breush-Pagan test which verify the absence of heteroscedasticity problem.

Table 5: Result of Breush-Pagan test

\begin{tabular}{|l||l|l|}
\hline & chi2 test & Prob>chi2 \\
\hline \hline$D A$ & 3.39 & 0.0656 \\
\hline$R E M$ & 2.64 & 0.0810 \\
\hline
\end{tabular}

\section{2. 3. Test of the individual effect presence}

It is important to identify the effect associated to every individual, otherwise it would be an effect that does not vary with time, but varies from one individual to an other. This effect can be a within or a random effect. The test of the individual effect existence rejects the hypothesis of the absence of the individual effects (Table 6). Thus, it is significant to specify the individual effects.

Table 6: Result of test presence individual effect

\begin{tabular}{|l|l|l|l|l||}
\hline & Fisher Value & P-value & $\boldsymbol{R}^{2}$ & \multicolumn{1}{c|}{ Conclusion } \\
\hline \hline $\boldsymbol{D A}$ & 11.25 & 0.0000 & 0.2030 & Existence of individual effects \\
\hline \hline $\boldsymbol{R E M}$ & 19.68 & 0.0000 & 0.3083 & Existence of individual effects \\
\hline
\end{tabular}

\section{2. 4. Hausman test}

It is necessary to choose what model is best suitable for our data: the within or the random model. Thus, we resort to Hausman test. Table 7 reveal that the value of Hausman test indicate that we must turn towards a random model of effects. In other words, the consideration of individual specificity of firms is under the shape of an uncertain effect which provides significant statistically better results in comparison to a model that is within individual effect.

\section{Table 7: Result of Hausman tests}

\begin{tabular}{|l|l|l|}
\hline & chi2 test & Prob>chi2 \\
\hline \hline DA & 2.23 & 0.9798 \\
\hline \hline REM & 5.17 & 0.6388 \\
\hline
\end{tabular}




\section{Mll Macrothink}

International Journal of Accounting and Financial Reporting ISSN 2162-3082 2012, Vol. 2, No. 2

\subsection{Results of the regressions}

We conduct Hausman test and the heteroscedasticity test to discriminate the suitable model. Table 8 presents the results of the equation's estimation, in which the relationship between the audit quality and earnings management was tested, the variables' coefficients, the expected sign as well as the associated probabilities.

Table 8: Results of regression

\begin{tabular}{|l||l|l||l||l|l|l||}
\hline \multicolumn{2}{|l|}{ DA } & \multicolumn{5}{l|}{ REM } \\
\hline \hline Variable & $\begin{array}{l}\text { Expected } \\
\text { sign }\end{array}$ & Coefficient & Probability & $\begin{array}{l}\text { Expected } \\
\text { sign }\end{array}$ & Coefficient & Probability \\
\hline \hline SPEC & - & $-0.024471 *$ & 0.057 & + & -0.048575 & 0.220 \\
\hline AUDSIZE & - & $-0.310784 * *$ & 0.025 & + & $0.130840 * *$ & 0.043 \\
\hline \hline TENURE & + & -0.048772 & 0.797 & + & -0.136769 & 0.416 \\
\hline ROA & - & $-0.442845 *$ & 0.062 & - & $0.372769 * *$ & 0.046 \\
\hline \hline MTB & - & 0.493850 & 0.548 & - & -0.016549 & 0.828 \\
\hline \hline LEV & + & 0.003239 & 0.804 & + & $-0.00503 *$ & 0.068 \\
\hline \hline LOGSIZE & - & -0.059869 & $0.059 *$ & + & 0.014105 & 0.893 \\
\hline \hline intercept & $?$ & 1.681886 & 0.068 & $?$ & 1.204206 & 0.162 \\
\hline
\end{tabular}

*,**, *** represents statistical significance at $0.1,0.05$ and 0.01 levels

Table 8 provides the regression results which allow us to examine the effect of the audit quality on earnings management. Our primary variable of interest, SPEC, is negatively associated $(\mathrm{p}=0.057)$ with the accruals earnings management as predicted by $\mathrm{H}_{2.1}$. These results are consistent with the theory that auditor industry specialization plays a role in enhancing audit quality. Indeed, firms that engage industry specialists to audit their external financial reports may benefit from a reduced likelihood of accruals earnings management (Dunn and Mayhew, 2004; Rusmin, 2010; Gul et al., 2010). However, Table 8 indicates also that the association between industry specialization and REM is insignificant ( $p=0.220$ ). Consequently, the hypothesis $\mathrm{H}_{2.2}$ is rejected. According to the hypothesis $\mathrm{H}_{1.1}$, Table 8 shows a significant influence of the auditors Big 4 on reducing accruals earnings management. Followings, of this table, the coefficient of AUDSIZE is negative (-0.310) and significant at the 5\% level ( $\mathrm{p}=0.025)$. This finding is similar to prior research (Krishnan, 2003; Choi et al., 2010). Table 8 shows a positive and significant association between the auditor size with REM ( $\mathrm{p}=0.043$ ). This result is consistent with Chi et al. (2010) and Cohen and Zarowin (2010) results which support that Big 4 auditors are positively related to REM. They suggest that more effective monitoring may motivate firms to manage earnings using techniques that are more difficult to identify. Consequently, the hypothesis $\mathrm{H}_{1.2}$ is accepted.

The results as reported in Table 8 show that the audit tenure coefficient is statistically insignificant for the Tunisian firms, suggesting that longer tenure is not associated with 
higher discretionary accruals. This result is similarly with the results of Simnett (2006) and Jackson et al. (2008) who found no relation between audit partner tenure and the absolute value of discretionary accruals. Consequently, the hypothesis $\mathrm{H}_{3.1}$ is rejected. Table 8 indicates also that longer auditor tenure is not associated with higher real earnings management. This result is inconsistent with the result of Chi et al. (2011) and Cohen and Zarowin (2010) who found that auditor tenure is associated with greater probability of using real earnings management. Consequently, the hypothesis $\mathrm{H}_{3.2}$ is also rejected.

Table 9: regression of the impact of audit quality on earnings management by integrating the variable "Law"

\begin{tabular}{|l||l|l|l|l|l|l|}
\hline \multicolumn{2}{||l|}{ DA } & \multicolumn{3}{l|}{ REM } \\
\hline Variable & $\begin{array}{l}\text { Expected } \\
\text { sign }\end{array}$ & Coefficient & Probability & $\begin{array}{l}\text { Expected } \\
\text { sign }\end{array}$ & Coefficient & Probability \\
\hline SPEC & - & $-0.02447 * *$ & 0.012 & + & -0.12427 & 0.327 \\
\hline \hline AUDSIZE & - & $-0.0104 * *$ & 0.048 & + & $0.13107 * *$ & 0.025 \\
\hline \hline TENURE & + & 0.02634 & 0.442 & + & -0.03521 & 0.339 \\
\hline \hline ROA & - & $-0.43973 *$ & 0.054 & - & $0.36547 *$ & 0.097 \\
\hline MTB & - & -0.49953 & 0.263 & - & -0.01795 & 0.815 \\
\hline \hline LEV & + & -0.00595 & 0.652 & + & -0.00189 & 0.880 \\
\hline \hline LOGSIZE & - & -0.08162 & 0.439 & + & $0.02635^{*}$ & 0.079 \\
\hline \hline Law & - & 0.08567 & 0.543 & + & -0.18323 & 0.169 \\
\hline
\end{tabular}

*,***** represents statistical significance at $0.1,0.05$ and 0.01 levels

Tunisia promulgated law $\mathrm{n}^{\circ} 2005-96$ which comes to control the companies, improve the transparency of financial information and reduce the manipulation. Before integrating the variable "law" like explanatory variable to test its impact on the REM, we carried out a test of CHOW which test the stability of the coefficients of regression on two different groups (before and after law $\mathrm{n}^{\circ}$ 2005-96). We have found that the calculated statistics are lower than the theoretical ones. Consequently, the two groups are statistically different. Therefore, the test proves that there are differences between the two groups. The results of regression (Table 9) show that the variable "law" haven't any effect on the reduction of the extent of the accruals earnings management in the Tunisian context ( $\mathrm{p}$-value $=0.543)$. In addition, the financial security law of 2005 doesn't associate with the increasing of REM (p-value $=0.169$ ). This result is inconsistent with Zang (2007), Graham et al. (2005), Gunny (2010) and Demers and Wang (2010). 


\section{Conclusion}

The purpose of this study is to examine if the adoption of financial security law of 2005 and the audit quality are associated with earnings management in the Tunisian context. This paper provides evidence that auditors' industry specialization and Big 4 auditors affects negatively the accruals earnings management, as documented in prior studies (Balsam et al., 2003; Reichelt and Wang, 2010; Jerry et al., 2010). One possible explanation of these results might be that auditors with industry expertise in the client's business are more likely to detect irregularities and misrepresentations and provide higher audit quality. However, the industry specialization doesn't have any effect on enhancing the REM in the Tunisian companies. The results show a negative and significant influence of the auditor size on reducing accruals earnings management. The results show also, a positive and significant association of the auditor size on REM. This result is consistent with Chi et al. (2011) and Cohen and Zarowin (2010). This study reveals that the long tenure is not associated with higher discretionary accruals in the Tunisian context. This result is similar to the results of Simnett (2006), Carcello and Nagy (2004) and Jackson et al. (2008). The paper provides also that the tenure hasn't any relation with the increasing of REM. This result is inconsistent with the result of Chi et al. (2011) and Cohen and Zarowin (2010).

Finally, we have found that the adoption of financial security law of 2005 by Tunisian companies has not reduced the use of discretionary accruals. Our results also have shown that the law $n^{\circ} 2005-96$ has not increased the use of REM.

Opportunities for further research could investigate other firm-specific factors such as family ownership, political connections and ownership concentration and other corporate governance mechanisms (audit committee and board of directors) which could affect the effectiveness of corporate governance in Tunisia.

\section{References}

Ahsen, H., 2011. Audit firm industry specialization and audit outcomes: Insights from academic literature. Research in Accounting Regulation, 23 (1), 114-129.

Balsam, S., Krishnan, G.V. and Yang, J.S., 2003. Auditor industry specialization and earnings quality. Auditing: a Journal of Practice \& Theory, 22 (2), 71-97.

Becker, C.L., DeFond, M.L., Jiambalvo, J. and Subramanyam, K.R., 1998. The effect of audit quality on earnings management. Contemporary Accounting Research, 15(1), 1-24.

Carcello, J. V. and Nagy, A. L., 2004. Client size, auditor specialization, and fraudulent financial reporting. Managerial Auditing Journal 19 (5): 651-668

Chen, Y. M., Moroney, R. and Houghton, K. 2005. Audit committee composition and the use of an industry specialist audit firm. Accounting and Finance, 45(2), 217-239.

Chi, W., Lisic, L. and Pevzner, M., 2011. Is Enhanced Audit Quality Associated with Greater Real Earnings Management? Accounting Horizons, 25 (2), 315-335.

Choi, J.H. and Wong, T., 2007. Auditors' Governance Functions and Legal Environments: An International Investigation'. Contemporary Accounting Research, 24 (1),13-46.

Choi, J. H., Kim, C., Kim, J. B. and Zang, Y., 2010. Audit office size, audit quality, and audit pricing. Auditing: A Journal of Practice \& Theory, 29 (1), 73-97. 
Cohen, D., and Zarowin, P., 2010. Accrual-based and real earnings management activities around seasoned equity offering. Journal of Accounting and Economics, 50, 2-19.

Cohen, D., Dey, A. and Lys, T., 2008. Real and accrual-based earnings management in the pre-and post-Sarbanes-Oxley periods. The Accounting Review, 83 (3), 757-787.

DeAngelo, L.E, 1981. Auditor size and audit quality. Journal of Accounting and Economics, 3 (3), 183-199.

Dechow, P.M., Kothari, S.P., and Watts, R.L. 1998. The relation between earnings and cash flows. Journal of Accounting and Economics, 25 (2), 133-168.

Dechow, P.M., Sloan, R.G. and Sweeny, A.P., 1995. Detecting earnings management. The Accounting Review, 70, 193-226.

Dunn, K.A. and Mayhew, B.W., 2004. Audit Industry Specialization and Client Disclosure Quality. Review of Accounting Studies, 9 (2), 35-58.

Francis, J.R., Mydew, E.L. and Sparks, H. C., 1999. The role of Big 6 auditors in the credible reporting of accruals. Auditing: a Journal of Practice and Theory, 18, 17-34.

Francis, J. R., and Yu, M. D., 2009. Big 4 office size and audit quality. The Accounting Review, 84 (5), 1521-1552.

Francis, J., and Wang, D. 2008. The joint effect of investor protection and Big 4 audits on earnings quality around the world. Contemporary Accounting Research, 25 (1), 157-191.

Gul, F.A., Kim, J.B. and Qiu, A.A., 2010. Ownership Concentration, Foreign Shareholding, Audit Quality, and Stock Price Synchronicity: Evidence from China. Journal of Financial Economics, 95 (3), 425-442

Gunny, K., 2010. The relation between earnings management using real activities manipulation and future performance: Evidence from meeting earnings benchmarks. Contemporary Accounting Research, 27(3), 855-888.

Graham, J., Harvey, R. and Rajgopal, S. 2005. The economic implications of corporate financial reporting. The Accounting Review, 80 (4), 1101-24.

Jaggi, B., Gul, F A and Chiu Lau, T. S., 2012. Auditor Industry Specialization, Political Economy and Earnings Quality: Some Cross-Country Evidence. Journal of International Financial Management and Accounting, 23 (1), 24-61.

Jenkins, D.S. and Velury, U., 2008. Does auditor tenure influence the reporting of conservative earnings? Journal of Accounting and Public Policy, 27 (2), 115-132.

Johnson, V., Khurana, I. and Reynolds, J., 2002. Audit-Firm Tenure and the Quality of Financial Reports. Contemporary Accounting Research, 19 (4), 637-660.

Jones, J. J., 1991. Earnings management during import relief investigations. Journal of Accounting Research, 29 (2), 193-228.

Jensen M, Meckling, W., 1976, Theory of the Firm: Managerial Behavior, Agency Costs and Ownership Structure. J. Finan. Econ., 3005-360.

Jordan C, Clark S and Hames, C., 2010. The impact of audit quality on earnings management to achieve user reference points in EPS. J. Appl. Bus. Res., 26 (1), 19-30.

Kim, J., Chung, R. and firth, M., 2003. Auditor Conservatism Asymmetric Monitoring 


\section{I Macrothink}

International Journal of Accounting and Financial Reporting

and Earnings Management. Contemporary Accounting Research, 20 (2), 323-359.

Krishnan, G.V., 2003. Does Big 6 auditor industry expertise constrain earnings management ? Accounting Horizons, 19 (1), 1-16.

Kwon, S.Y., Lim, C.Y. and Tan, P.M., 2007. Legal Systems and Earnings Quality: The Roleof Auditor Industry Specialization. Auditing: A Journal of Practice \& Theory, 26, pp. 25-55.

Lawrence, A., Minutti-Meza, M., and Zhang, P., 2011. Can Big 4 versus non-Big 4 difference in audit-quality proxies be attributed to client characteristics? The Accounting Review, 86 (1), 259-286.

Lim, C.Y. and Tan, P. M. S. 2009). Control divergence, timeliness in loss recognition, and the role of industry specialization: Evidence from around the world, Journal of Accounting, Auditing and Finance, 24(2), 295-332

Lin, J.W and Hwang, M.I, 2010). Audit quality, corporate governance, and earnings management: a meta-analysis. Int. J. Audit., 14 (1), 57-77.

Myers, J., Myers, L. and Omer, T., 2003. Exploring the term of the auditor-client relationship and the quality of earnings: A case for mandatory auditor rotation? The Accounting Review, 78, 779-99.

Reichelt, K. J., and Wang, D., 2010. National and office-specific measures of auditor industry expertise and effects on audit quality. Journal of Accounting Research, 48 (3), 647-686.

Roychowdhury, S., 2006. Earnings management through real activities manipulation. Journal of Accounting and Economics, 42, 335-370.

Rusmin, R., (2010). Auditor quality and earnings management: Singaporean evidence. Managerial Auditing Journal, 25 (7), 618-638.

Zang, A., 2007. Evidence of the tradeoff between real manipulation and accrual manipulation. working papers, University of Rochester.

Zhou, J., and Elder, R., 2004. Audit quality and earnings management by seasoned equity offering firms. Asia Pacific Journal of Accounting and Economics, 11(2), 95-120. 